Impact Factor: 4.845(SJIF) Research Journal Of English (RJOE) Vol-5, Issue-1, 2020

www.rjoe.org.in An International Peer-Reviewed English Journal

ISSN: 2456-2696

Indexed in: International Citation Indexing (ICI), International Scientific Indexing (ISI), Directory of Research Journal Indexing (DRJI) Google Scholar \& Cosmos.

\title{
AN-ECO-CRITICAL READING OF INDIAN WOMEN BOOKER WINNERS
}

\author{
Dr. Bipin Bihari Dash \\ Assistant Professor of English \\ C.E.T., Bhubaneswar, India
}

\begin{abstract}
:
The twenty-first century is an era of the growth and development of science and technology. This is also the age of environmental destruction. This is because of man's irresponsible attitude and treatment towards the natural world. It is not only the consequence of increasing use of technology in human life but also an imperceptible change in human being's mentality that fails to recognise the inter-relationship of all things existing in the world. As a result such a misbalanced view of progress in due course of time compelled human beings to make their approach bio-centric (earth centred) so that the natural environment may be protected and its balance with human life may be maintained. In this context, many plans/schemes are being launched by the government for saving the environment and making the people aware about environment. Many novelists have become eco-conscious or environment conscious in their writings. They have used Nature as landscape, as beautiful atmosphere or lively atmosphere. Thus literature has become a mode of expression about environment and it's important in human life and universe. Simultaneously, Eco-critical theory investigates the relationship between human activities and the natural world, particularly in terms of the influence of each upon the other. The present paper highlights how Kiran Desai, the disaporic writer and Arundhati Roy, the non-expatriate writer have expressed their treatment of ecology in their literary works. The eco-critical insight undertaken in this paper would contribute to a new dimension of thought, feeling and emotion.
\end{abstract}

Key Words: Ecology, Environment, Eco-criticism, Literature, Culture

\section{Meaning of Ecology, Environment and Eco-criticism}

Ecology is the branch of biology that deals with the relations of organisms to one another and to their physical surroundings. Environment means the surroundings or conditions in which a person, animal or plant lives or operates. In a nut-shell, we can say that eco-criticism is a literary theory that is a holistic approach to nature, environment, landscape, biotic and a biotic and ecosystem which is represented through the study of different genres of literature.

\section{History of the term Eco-criticism}

The term 'eco-criticism' was first introduced by William Rueckert in his essay Literature and Ecology: An Experiment in Ecocriticism, published in 1978. Here he described it as "the 
Impact Factor: 4.845(SJIF) Research Journal Of English (RJOE) Vol-5, Issue-1, 2020

www.rioe.org.in An International Peer-Reviewed English Journal

ISSN: 2456-2696

Indexed in: International Citation Indexing (ICI), International Scientific Indexing (ISI), Directory of Research Journal Indexing (DRJI) Google Scholar \& Cosmos.

application of ecology and ecological concept of the study of literature." The extensive use of the term commenced with WLA (World Literature Association) conference in USA in 1989, when Cheryll Glotfelty, an Associate Professor of Literature and the Environment at the University of Nevada Reno, revived the term and made an appeal to its adoption to refer the dispersed critical field, earlier known as 'the study of nature writing.' Later, with the publication of two seminal works The Ecocriticsm Reader: Landmarks in Literary Ecology (1996) edited by Cheryll Glotfelty and Harold Fromm and The Environmental Imagination (1996) by Lawrence Buell, in 1996, the term heralded with a boom.

Jonathan Bate, Professor of English Literature at the University of Liverpool, published his famous book Romantic Ecology, Wordsworth and the Environmental Tradition in 1991 where he read the writings of the romantic poets to seek a balance of culture and nature. He recognised Wordsworth to be an example of eco-critical thinker who viewed nature not as an outward entity but an integral part of human sensibility. His appeal to human beings to "see into the life of things" clearly indicates his anxiety about the growing indifferent attitude of man towards nature. Bate's The Song of the Earth is the latest contribution to the field of ecocriticism. Here he makes a plea for "an imaginative re-unification of mind and nature."

\section{Why Natural Environment?}

The natural environment encompasses all living and non-living things occurring naturally. This environment comprehends the interaction of all living species, climate, weather and natural resources that affect human survival and economic activity. It's everything that makes up our surroundings and affects our ability to live on the earth - the air we breathe the water that covers most of the earth's surface, the plants and animals around us, and much more.

\section{Indian Women Booker winners}

It is significant to note that there are two women writers in India who have won the Man Booker prize for literature so far. They are Kiran Desai, and Arundhati Roy. Both of them are deeply concerned with nature and environment through their representation of literary works.

Compelled by the idea of saving environment from total chaos, the current writes have made it a challenge to deal with nature as an important entity in their literary texts. When these texts are studied from eco-critical perspective, the readers find the inter-relatedness of all the factors within the ecosystem like social, political and phenomenon of natural world. Even the physical setting in the plot of the literary text plays an important role in the total understanding of its meaning.

Kiran Desai, daughter of an eminent novelist, Anita Desai, is a young and vibrant Indian English novelist with innate artistic talents. Having emerged on the Indian English scene in late 1990s she has created a distinct place for herself in the galaxy of Indian women novelists 
Impact Factor: 4.845(SJIF) Research Journal Of English (RJOE) Vol-5, Issue-1, 2020

www.rjoe.org.in An International Peer-Reviewed English Journal

ISSN: 2456-2696

Indexed in: International Citation Indexing (ICI), International Scientific Indexing (ISI), Directory of Research Journal Indexing (DRJI) Google Scholar \& Cosmos.

in English. Her debut novel Hullabaloo in the Guava Orchard (1998) artistically presents human foibles and eccentricities in a satirical tone. She has leapt into fame and won international acclaim with the publication of her The Man Booker Prize Winning novel The Inheritance of Loss (2006) which on the one hand deals with social, political, and economic problems of the people of contemporary society in India and, on the other the social and psychological problems faced by Indian immigrants in America and England. The novel explores contemporary international issues such as globalisation, multiculturalism, economic inequality, fundamentalism, terrorist violence, immigration, racial discrimination, postcolonialism, alienation, exile, and westernisation. The concern about nature is also significant one.

The novel The Inheritance of Loss appeals the reader at the very first reading, for its ecocentric approach. Her description of mountains and the people of Kalimpong, the changing seasons and the inner mindscape of her characters are mesmerizing.

What strikes us most is her observation of minute details of characters at every nook and cranny of their living space. In fact, sustained vigour of her narrative keeps the reader spell bound. The exposition of the novel's setting and characters in the background of Kanchenjunga and its majestic summit is a fascinating portrayal of Nature's beauties and bounties. The readers of Kiran Desai recapture this colourful picture in the first paragraph of chapter one.

\section{Desai writes:}

All day, the colors had been those of dusk, mist moving like a water creature across the great flanks of mountains possessed of ocean shadow and depths. Briefly visible above the vapour, Kanchenjunga was a far peak whittled out of ice, gathering the last of the light, a plume of snow blown high by the storms at its summit. (IL 1)

Thus, Kanchenjunga provides the beautiful locale of the characters and their topography with mist moving like a water creature across the great flanks of mountains possessed of ocean shadows and depths. As the novel progresses Kanchenjunga appears in colourful ways with the change of seasons.

The achievement of Desai lies in integrating the themes with the landscape of the place which goes a long way to make The Inheritance of Loss a truly evocative novel. The ending is symbolic and significant. Desai writes:

The five peaks of Kanchenjunga turned golden with the kind of luminous light that made you feel, if briefly, that truth was apparent. All you needed to do was to reach out and pluck it (IL 324). 
Impact Factor: 4.845(SJIF) Research Journal Of English (RJOE) Vol-5, Issue-1, 2020

www.rjoe.org.in An International Peer-Reviewed English Journal

ISSN: 2456-2696

Indexed in: International Citation Indexing (ICI), International Scientific Indexing (ISI), Directory of Research Journal Indexing (DRJI) Google Scholar \& Cosmos.

It is pertinent to note that our ecosystem gets disturbed in the name of national security and protection of cultural heritage. Those who used to live the place in complete harmony with nature are turned off in the name of big political jargons, especially in "areas of high sensibility" (IHL 221) Like Kalimpong. Father Booty who used to live here for more than forty years, all of a sudden is asked about his nationality and the decision is taken by the government authorities to turn him off from his fine and beautiful shelter.

Kiran Desai employs 'rain' as a central metaphor to reveal the love relationship. Sai and Gyan also could not save themselves from its spell bound charm. Their emotions get uncontrolled midst the gusty winds of monsoon. So, nature plays an important role in their lives. Even the nick names they selected for each other were taken from the beautiful objects of nature-Sai called Gyan "Kaju" and he called her "Khismish".

Nature is the source of enormous energy, provided we aspire to use it. In today's world, man suffers from the permanent fatigue syndrome and to overcome it, the easiest way is the lap of nature, where nature would heal our impaired faculties and rejuvenate us for further efforts. For example, in the novel, when Sai asked to her grandfather the Judge Jemubhai Patel about her grandmother, he intentionally avoided her and went to garden to compensate his pain. In fact, this indicates how nature is practically soothing to human beings.

Kiran Desai's debut novel Hullabaloo in the Guava Orchard (1998), on the one hand, manifests Nature as a source of peace and tranquillity; on the other hand, it also throws light on the estranged relationship of man with his environment.

"Hullabaloo in the Guava Orchard," is a tale of a young man named Sampath Chawla, the protagonist of the novel who lives in the town of Shahkot, India. He is born on the night a severe drought ends when a ferocious monsoon sweeps over the region. The setting of the story is in a small town, Shahkot where the weather is intolerably hot. With no sign of monsoon's arrival, there were dozens of monsoon inducing proposals such as the army's proposal for "scattering and driving of clouds by jet planes flying in a special geometric formation" and the proposal of the police for "a frog wedding to be performed by temple priests" (HGO 2). Sampath is born on the day of great relief for the town when there comes a thunderous shower of rain after the scorching summer heat and there is the dropping of food supplies from a Swedish relief plane.

Whenever there is natural disaster people from all strata of society try to find out solution. Their activities reflect cultural beliefs and rituals. Temple priest thought of wedding of frog to bring rain. Various creatures are commonly associated with cultural rituals. They play important role in mythology of cultures. Ironically speaking they are becoming fool by the nature. They should understand they are responsible for this curse of nature. 
Impact Factor: 4.845(SJIF) Research Journal Of English (RJOE) Vol-5, Issue-1, 2020

www.rjoe.org.in An International Peer-Reviewed English Journal

ISSN: 2456-2696

Indexed in: International Citation Indexing (ICI), International Scientific Indexing (ISI), Directory of Research Journal Indexing (DRJI) Google Scholar \& Cosmos.

'Hullabaloo in the Guava Orchard' embodies the ecological idea on the relationship between man and nature, between man and man, and between man and self. Kiran Desai confronts in this novel serious issue of environmental crisis. Novel begins with introducing global environmental crisis i.e. global warming and its implications.

Away from tremendous familial pressures to perform well and from societal expectations, Sampath finds tranquillity in the lap of Mother Nature in communication with the creatures of the earth. He had decided to remain there forever, whatever may come. Overnight he was defiled, and became what some called a 'Monkey Baba', others 'Tree Baba' because his dwelling place was the guava orchard. He started giving what was called 'The Sermon in the Guava Tree'. The unfathomable wisdom came in an inspired moment of self-preservation. Beautiful and peaceful atmosphere of orchard hold Sampath spellbound.

The Baba loved the monkeys, who jumped up on the tree top. He liked their company, their pranks and felt absolutely at home (pun intended) when they played around him. This brings out a true relationship between human beings and animals.

It is important to point out that the spiritual energy comes from nature, including his indicative birth, the initiation into the orchard, and Kulfi's (Sampath's mother) fantastic cuisine made of natural ingredients. Moreover, the Guava is a product of nature. From a spiritual point of view, this shares a kind of homogeneity with nature.

Finally, the guava carries its seeds which fall in the ground where new guava sapling sprout. Metaphorically, as a form of transformation, the guava represents fertility. Although fertility is mostly concerned with the issue of childbearing, it also refers to the continuity of a society. In fact nature and human beings are interconnected.

Arundhati Roy is one of the most outstanding Indian English novelists of the post-colonial period. She has astonished the literary world by winning the Booker Prize for her novel The God of Small Things in the year 1997. The novel depicts the life of Keralite society and its rites, customs, traditions, and patriarchal domination, caste apartheid and discrimination. Consequently, Kerala has been in the national and global limelight. The state has witnessed significant social, political, and cultural movements including struggles for eradication of untouchability and other social problems. Roy focuses on the traumatic experiences of nature and environment in her novels.

The God of Small Things deals with nature and environment. The novelist tries to show the harmful effect of urbanization on environment. River was the source that made early men changes their lifestyle by making them settle on river banks. History exposes the fact that all civilizations flourished only in riverbeds. River is the chief source of water, which is one of 
Impact Factor: 4.845(SJIF) Research Journal Of English (RJOE) Vol-5, Issue-1, 2020

www.rioe.org.in An International Peer-Reviewed English Journal

ISSN: 2456-2696

Indexed in: International Citation Indexing (ICI), International Scientific Indexing (ISI), Directory of Research Journal Indexing (DRJI) Google Scholar \& Cosmos.

the life sustaining elements in this earth. Meenachal is the river of Ayemenem that made human beings think about agriculture and become the source of livelihood. But now its condition is pitiable.

When technology and its products have become the priority of people, they tend to ignore nature. This is clearly reflected through the character of Baby Kochamma, the aunt of Raphel's and Estha's mother. She took great care of her garden. Later, she lost interest in gardening when she installed a dish antenna on the roof of the house. The 'satellite TV' became her 'new love' and she completely ignored her garden.

Roy brings out how Ayemenem was and how it is at present through the following lines:

"Here too, houses had mushroomed, and it was only the fact .........In truth, its population had swelled to the size of a little town." (GST 128)

In fact, this indicates that population explosion is a problem even in a village in India.

\section{Conclusion}

To conclude, I may point out that nature has been interwoven with texts in such an artistic manner that they have become the persistent source of guiding, motivating, inspiring and enlightening those who read, evaluate and execute it in the real life situations. The novels deal not only with the life style of the inhabitants but also its landscape. They remind us of non-human perspectives like trees, rivers, mountains, and animals and their relevance in the total understanding of environment. Ecological balance is the foremost need of today and the novelists have tried to intensify this need through their texts.

\section{References:}

- Barry, Peter. Beginning Theory: An Introduction to Literary and Cultural Theory, New Delhi: Viva Publication, 2007. Print. 252.

- Desai, Kiran. Hullabaloo in the Guava Orchard. New Delhi: Penguin Books, 1998. Print.

- $\quad$ The Inheritance of Loss, New Delhi: Penguin Books, 2006. Print.

- Nayar, Pramod K., Literary Theory Today, New Delhi: Prestige, 2006. Print. 291.Roy, Arundhati,: The God of Small Things, New Delhi: Penguin Books, 1997. Print.

- Sharma, R.S. 1998. Arundhati Roy's The God of Small Things: Critique and Commentary. NewDelhi: reative Books.

- Sinha, Sunita and Bryan Reynolds. Critical Responses to Kiran Desai, New Delhi: Atlantic Publisher, 2009. Print. 